\title{
Penggunaan Model-Eliciting Activities (MEAs) Untuk Meningkatkan Kemampuan Berpikir Reflektif Pada Pembelajaran Geometri Transformasi
}

\author{
Septiana Wijayanti' ${ }^{1)}$, Triyono ${ }^{2)}$, M. Wahid Syaifuddin ${ }^{3)}$ \\ 1),2),3) Pendidikan Matematika UNWIDHA Klaten \\ septiana.wijaya@unwidha.ac.id
}

\begin{abstract}
Abstrak
Penelitian tindakan kelas ini bertujuan mengetahui peningkatan kemampuan berpikir reflektif dan hasil belajar matematika dengan menggunakan Model-Eliciting Activities (MEAs). Subjek penelitian adalah mahasiswa yang mengikuti mata kuliah Geometri Transformasi. Data berupa RPP, foto, observasi, daftar nilai dan hasil tes. Teknik pengambilan data dilakukan dengan cara observasi, dokumentasi dan tes prestasi belajar matematika. Uji validasi data melalui observasi terus menerus dan triangulasi sumber. Teknik analisis data melalui reduksi data, analisis data dan penarikan kesimpulan. Hasil penelitian menyimpulkan dengan menggunakan ModelEliciting Activities (MEAs) meningkatkan kemampuan berpikir reflektif, hal ini terlihat dari siklus I jumlah mahasiswa yang mempunyai kemampuan berpikir reflektif sebanyak 6 mahasiswa (25\%) menjadi 15 mahasiswa (62.5\%) pada siklus II. Pembelajaran dengan menggunakan Model-Eliciting Activities (MEAs) juga meningkatkan hasil belajar matematika, terlihat dari mahasiswa yang tuntas dalam KKM sebelum dilakukan tindakan 8 mahasiswa (33.33\%), setelah dilakukan tindakan pada siklus I mahasiswa yang tuntas sebanyak 9 mahasiswa (37.5\%) meningkat menjadi 14 mahasiswa (58.33\%) pada siklus II. Peningkatan hasil belajar juga tampak dari rerata klasikal sebelum diberikan tindakan sebesar 57.92; setelah diberikan tindakan pada siklus I menjadi 67.79 serta rerata pada siklus II menjadi 75.42.
\end{abstract}

Kata Kunci: Model-Eliciting Activities (MEAs), berpikir reflektif, hasil belajar

\section{PENDAHULUAN}

Pendidikan Matematika merupakan salah satu program studi di Universitas Widya Dharma yang mempunyai visi "menjadi program studi yang menyiapkan lulusan yang memiliki kompetensi tinggi dalam bidang pendidikan matematika demi terwujudnya kesejahteraan bangsa berlandaskan mulitikultur". Oleh karena itu, program studi pendidikan matematika mempunyai tanggung jawab untuk mengembangkan segala potensi mahasiswa dengan menyelenggarakan pendidikan dan pengajaran yang kreatif dan inovatif sehingga mahasiswa mempunyai keterampilan, pengetahuan dan sikap yang sesuai dengan tujuan pendidikan.

Program Studi Pendidikan Matematika tentunya memberikan bekal bagi caloncalon lulusannya dengan mata kuliah pada rumpun aljabar, geometri, statistika, hingga pada perkuliahan berbasis pendidikan. Salah satunya adalah perkuliahan Geometri Transformasi. Menurut (Hollebrands, 2003) menunjukkan bahwa pemahaman siswa tentang konsep-konsep domain, variabel dan parameter, dan hubungan sifat-sifat transformasi sangat penting untuk mendukung pengembangan pemahaman yang lebih dalam tentang transformasi sebagai fungsi.

Pada proses pembelajaran dapat dilihat bagaimana pola kerja mahasiswa dalam menyelesaikan soal dan hasil belajar mahasiswa. Untuk melihat pola kerja mahasiswa dalam menyelesaikan soal, dalam penelitian ini focus pada kemampuan berpikir reflektif. Kemampuan berpikir reflektif adalah sebagai proses kegiatan terarah dan tepat dimana individu menyadari untuk diikuti, menganalisis, mengevaluasi, 
memotivasi, mendapatkan makna yang mendalam, menggunakan strategi pembelajaran yang tepat (Gurol, 2011). Dengan demikian berpikir reflektif guru bertujuan untuk mencapai target belajar dan menghasilkan pendekatan pembelajaran baru yang berdampak langsung pada proses belajar. Lebih jauh dijelaskan bahwa proses pemikiran reflektif dapat digunakan dalam proses belajar dan mengajar (pembelajaran) oleh calon guru dan siswa (Suharna, 2012). Lebih lanjut menurut (Bugg \& Dewey, 2006) berpikir merupakan proses yang menghasilkan representasi mental yang baru melalui transformasi informasi yang melibatkan informasi yang kompleks antara berbagai proses mental, seperti penilaian, abstraksi, penalaran, imajinasi, dan pemecahan masalah.

Selanjutnya, hasil belajar pada mata kuliah Geometri Transformasi saat ini belum optimal. Pada tahun ajaran 2017/2018 hanya 40\% mahasiswa yang menguasai materi. Melihat kondisi yang ada, maka peneliti tertarik untuk melakukan penelitian mengenai penggunaan Model-Eliciting Activities (MEAs) untuk meningkatkan kemampuan berpikir reflektif pada pembelajaran Geometri Transformasi.

\section{METODE PENELITIAN}

Penelitian ini dilakukan di Universitas Widya Dharma Klaten. Penelitian ini merupakan penelitian tindakan kelas (PTK). Subjek dalam penelitian adalah mahasiswa Program Studi Pendidikan Matematika yang mengikuti mata kuliah Geometri Transfromasi yang berjumlah 24 mahasiswa. Data berupa RPP, foto, observasi, daftar nilai dan hasil tes. Teknik pengambilan data dilakukan dengan cara observasi, dokumentasi, dan diskusi untuk memperoleh data kulaitatif sedangkan tes prestasi belajar matematika dilakukan untuk memperoleh data kuantitatif. Uji validasi data melalui observasi secara terus menerus dan triangulasi sumber. Teknik analisis data melalui reduksi data, analisis data dan penarikan kesimpulan. Analisis data dilakukan sejak tindakan pembelajaran dilaksanakan. Data awal didapatkan dari pretest untuk melihat penguasaan mahasiswa terhadap materi Geometri Transformasi sebelum dilakukan tindakan.

Indikator yang ingin dicapai dalam penelitian ini adalah meningkatnya kemampuan berpikir reflektif matematika dan meningkatnya hasil belajar matematika siswa dengan menggunakan Model-Eliciting Activities (MEAs). Pembelajaran dikatakan berhasil apabila ada peningkatan indikator kemampuan berpikir reflektif dan ada peningkatan hasil belajar yang dapat dilihat dari ketuntasan mahasiswa dalam pembelajaran Geometri Transformasi. Adapun indikator keberhasilan untuk peningkatan kemampuan berpikir reflektif yaitu: (1) menganalisis dan mengklarifikasi pertanyaan dan jawaban; (2) mengeneralisasi dan menganalisis generalisasi; (3) membedakan antara data yang relevan dan yang tidak relevan; (4) memecahkan masalah matematis

Proses pembelajaran dikatakan berhasil apabila (1) dalam siklus I dosen melaksanakan pembelajaran sesuai prosedur Model-Eliciting Activities (MEAs) tetapi kurang maksimal, maka dalam siklus akhir dosen melaksanakan pembelajaran sesuai prosedur Model-Eliciting Activities (MEAs) secara optimum, (2) terjadi perubahan kemampuan berpikir reflektif matematika pada siklus I kurang dari $30 \%$ dan rata-rata presentase kreativitas pemecahan masalah matematika pada akhir siklus lebih dari $60 \%$, (3) rata-rata nilai mahasiswa meningkat dari siklus I ke siklus berikutnya. (4) melalui tes evaluasi di akhir siklus pembelajaran, $75 \%$ mahasiswa yang mengikuti mata kuliah Geometri Transfromasi mengalami ketuntasan belajar dalam pembelajaran. 


\section{HASIL DAN PEMBAHASAN}

Penelitian yang diterapkan pada penelitian guna meningkatkan kemampuan berpikir reflektif matematika adalah pembelajaran dengan Model-Eliciting Activities (MEAs) yang dilaksanakan di kelas Geometri Transformasi. Penelitian dilaksanakan pada Januari 2019 sampai dengan Agustus 2019. Pokok bahasan yang dipelajari adalah seluruh materi Geometri Transformasi. Penelitian dilaksanakan dengan 2 siklus dengan masing-masing siklus terdiri dari 2 pertemuan.

Pembelajaran matematika dengan Model-Eliciting Activities (MEAs) dapat meningkatkan kemampuan berpikir reflektif matematika pada mahasiswa. Pelaksanaan tindakan kelas siklus I bahwa pembelajaran dengan Model-Eliciting Activities (MEAs) belum begitu mengena kepada mahasiswa, terlihat dari interaksi yang terjadi masih kurang. Hal ini masih perlu diadakan perbaikan pada siklus selanjutnya karena hasil yang dicapai belum mengalami peningkatan yang signifikan. Rencana tindakan siklus I perlu direvisi dan hasilnya digunakan untuk acuan pada pelaksanaan tindakan siklus II. Dalam pertemuan berikutnya, dosen harus memberikan motivasi yang lebih untuk meningkatkan kemampuan berpikir reflektif matematika. Tindakan kelas siklus II telah mengalami peningkatan yang berarti, hal ini dapat terlihat dari beberapa aspek kemampuan berpikir reflektif telah mengalami peningkatan secara signifikan dan respon siswa mengenai materi sangat baik dalam pembelajaran.

Kemampuan berpikir reflektif matematika pada mahasiswa dalam mata kuliah Geometri Transformasi dengan menerapkan Model-Eliciting Activities (MEAs) di setiap siklus mengalami peningkatan, yaitu : (1) mahasiswa dengan kemampuan berpikir pra reflektif, sebelum dilakukan penelitian sebanyak 18 mahasiswa (75\%), pada siklus I sebanyak 10 mahasiswa (41.67\%), pada siklus II sebanyak 3 mahasiswa (12.5\%), (2) mahasiswa dengan kemampuan berpikir reflektif kuasi, sebelum penelitian sebanyak 5 mahasiswa (20.83\%), pada siklus I sebanyak 8 mahasiswa (33.33\%), pada siklus II sebanyak 6 mahasiswa (25\%), (3) mahasiswa dengan kemampuan berpikir reflektif, sebelum tindakan sebanyak 1 mahasiswa (4.17\%), pada siklus I sebanyak 6 mahasiswa (25\%), pada siklus II sebanyak 15 mahasiswa (62.5\%). Peningkatan kemampuan berpikir reflektif matematika dapat dilihat pada Tabel 1 dan Gambar 1 berikut.

Tabel 1. Rangkuman Kemampuan Berpikir Reflektif

\begin{tabular}{lcccc}
\multicolumn{1}{c}{ Tahapan } & Siklus I & \multicolumn{2}{c}{ Siklus II } \\
& Frekuensi & $\%$ & Frekuensi & $\%$ \\
\hline Pra Reflektif & 10 & 41.67 & 3 & 12.5 \\
Reflektif Kuasi & 8 & 33.33 & 6 & 25 \\
Reflektif & 6 & 25 & 15 & 62.5 \\
\hline
\end{tabular}

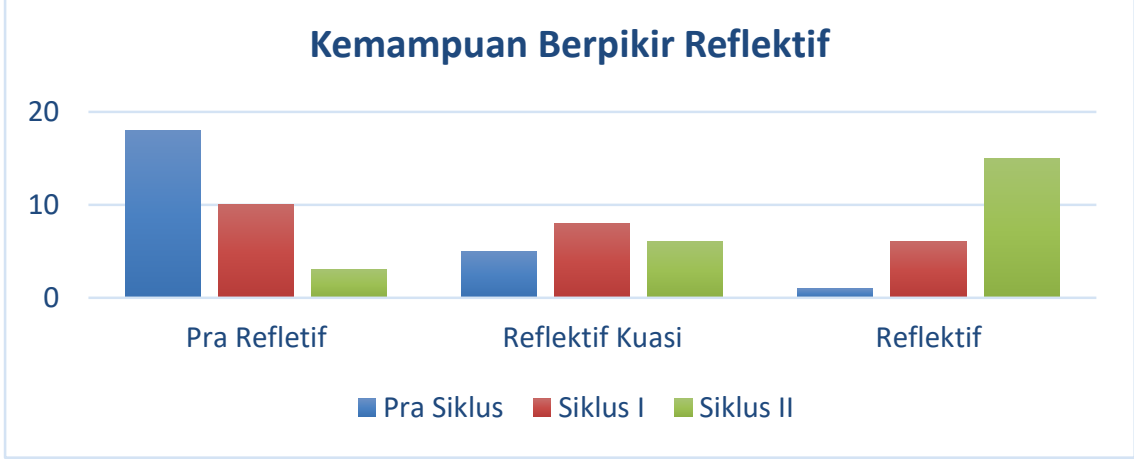

Gambar 1 Grafik Kemampuan berpikir reflektif 
Menurut (Fuady, 2017) berfikir reflektif penting bagi anak untuk memecahkan masalah matematika. Proses berpikir reflektif tidak tergantung pada pengetahuan siswa semata, tapi proses bagaimana memanfaatkan pengetahuan yang telah dimilikinya untuk memecahkan masalah yang dihadapi. Jika siswa dapat menemukan cara untuk memecahkan masalah yang dihadapi sehingga dapat mencapai tujuannya maka siswa tersebut telah melakukan proses berpikir reflektif.

Pembelajaran matematika dengan Model-Eliciting Activities (MEAs) juga dapat meningkatkan hasil belajar matematika pada mahasiswa Geometri Transformasi. Hasil belajar sebelum dilaksanakan pembelajaran dengan Model-Eliciting Activities (MEAs), siswa yang mendapatkan nilai di atas KKM sebanyak 8 mahasiswa (33.33\%) dan setelah dilaksanakan pembelajaran dengan Model-Eliciting Activities (MEAs) mahasiswa yang mendapatkan nilai di atas KKM sebanyak 14 siswa (58.33\%). Berdasarkan Tabel 2 dan Gambar 2 menunjukkan bahwa rata-rata mengalami peningkatan dari siklus I dengan rata-rata 58.33 menjadi 75.42 pada siklus II. Hal ini dapat disimpulkan bahwa penerapan model eliciting activities dapat meningkatkan hasil belajar mahasiswa

\section{Tabel 2. Rangkuman Hasil Belajar}

\begin{tabular}{clc}
\hline No. & \multicolumn{1}{c}{ Siklus } & Rata-rata \\
1 & Siklus I & 58.33 \\
2 & Siklus II & 75.42 \\
& & \\
\hline
\end{tabular}

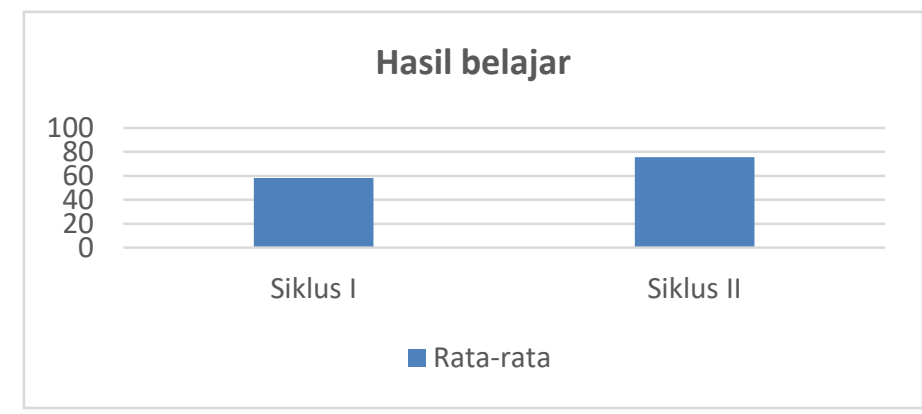

\section{Gambar 2 Grafik Kemampuan berpikir reflektif}

Penelitian lain yang terkait adalah (Jumaidi, 2017) yang menyatakan bahwa penerapan model pembelajaran Model-eliciting Activities (MEAs) dapat meningkatkan kemampuan pemecahan masalah siswa. peningkatan kemampuan pemecahan masalah yang terjadi sebesar $45.45 \%$.

\section{SIMPULAN DAN SARAN}

Pembelajaran dengan menerapkan model eliciting activities dapat meningkatkan kemampuan berpikir reflektif. Hal ini terlihat dari siklus I jumlah mahasiswa yang mempunyai kemampuan berpikir reflektif sebanyak 6 mahasiswa (25\%) menjadi 15 mahasiswa (62.5\%) pada siklus II. Pembelajaran dengan menerapkan model eliciting activities dapat meningkatkan hasil belajar mahasiswa. Hal ini terlihat dari hasil evaluasi pada siklus I dengan rata-rata 58.33 menjadi 75.42 pada siklus II.

\section{DAFTAR PUSTAKA}

Bugg, E. G., \& Dewey, J. (2006). How We Think: A Restatement of the Relation of Reflective Thinking to the Educative Process. The American Journal of Psychology. 
https://doi.org/10.2307/1415632.

Fuady, A. (2017). Berfikir reflektif dalam pembelajaran matematika. Jurnal IImiah Pendidikan Matematika, 1(2), 104-112.

Gurol, A. (2011). Determining the reflective thinking skills of pre-service teachers in learning and teaching process. Energy Education Science and Technology Part B: Social and Educational Studies.

Hollebrands, K. F. (2003). High School Students' Understanding of Geometric Transformations in the Context of a Technological Environment. Journal of Mathematical Behavior, 22(1), 55-72.

Jumaidi. (2017). Penerapan Pendekatan Model-Eliciting Activities (MEAs) Dalam Meningkatkan Kemampuan Pemecahan Masalah Siswa Kelas XII SMA N 2 Yogyakarta. Aksioma, 8(2), 43-49.

Suharna, H. (2012). Berpikir Reflektif (Reflective Thinking) Siswa SD Berkemampuan Matematika Tinggi Dalam Pemahaman Masalah Pecahan. In Seminar Nasional Matematika dan Pendidikan Matematika dengan tema "Kontribusi Pendidikan Matematika dan Matematika dalam Membangun Karakter Guru dan Siswa" (pp. 377-386). Yogyakarta. 